\title{
Enhancing Posing-Problem Skill in Linear Program by GeoGebra-Assisted
}

\author{
N Puspitasari ${ }^{1}$, D Sofyan, R Sundayana, R Nuraeni, I P Luritawaty \\ \{puspita6881@gmail.com ${ }^{1}$ \} \\ Institut Pendidikan Indonesia
}

\begin{abstract}
GeoGebra is a Dynamic Mathematics Software for teaching and learning mathematics from middle school through college level. GeoGebra can help understanding and facilitate mathematics learning. Problem Posing is an activity to formulate problems. Problem posing skill are very helpful in developing mathematical abilities including the ability to think creatively, and solve problem. The purpose of this study was to determine the effectiveness of using GeoGebra in a Linear Program towards increasingproblem posing abilities. This research method is quasi-experimental. The results of this study concluded that use of GeoGebra in the Linear Program was effective in increasing problem posing skills.GeoGebra assisted learning is an alternative to improve problem posing skills.
\end{abstract}

Keywords: Problem Posing, GeoGebra, Linear Program

\section{Introduction}

In general it can be said that the goal of most cognitive important of education in every level are the learners able to resolve the issue [1], [2], [3]. In higher Education, problem-solving ability is explicitly stated in the standard competence of graduates of S-1 should be at the level of six based on Bloom's taxonomy. However, to be able to resolve the problem required the ability to apply mathematical problem or known by the term mathematical problem posing. Mathematical problem posing is the content that is essential in mathematics and the nature of thinking of mathematical, as well as an important part of mathematical problem solving. The ability of mathematical problem posing becomes an important ability to master students because through mathematical problem posing can develop the ability mathematically which requires the ability to imagine creative mathematically that can be developed at the time gave rise to new questions, create new opportunities and looked at the old question from a new viewpoint [4], [5], [6], [7]. At the time of the process of problem posing student conduct process problem formulation which is the essential thing rather than solving the problem [8]. The facts on the ground, students prefer to directly solve the problem of mathematical rather than mathematical problem posing [9].

The term problem posing related to problem finding, problem sensing, problem formulating, creative problem discovery, problem creating, problematizing, and problem envisaging [10]. The term problem posing contains the sense of identifying a new problem or a new question of a series of data or information available. English defines problem posing as a form of creative activity of the individual which takes place in a context that is associated with the experience of the past that then there is interaction between the knowledge that has been owned by the new information that it faces [5]. 
Mathematical problem posing includes the ability to think high level. To be able to develop fluency and the ability to think high level is required a medium that can motivate students to want to continue to do a process of trial and error in the exercise of mathematics. One of the media used in this study namely by using GeoGebra. GeoGebra has become a tool that can help teachers to design effective instructional lessons [11]. GeoGebra is free algebra, geometry and calculus software developed in the University of Cambridge Education Institute [12]. GeoGebra is free open-source dynamic software for mathematics teaching and learning that offers geometry and algebra features in a fully connected software environment [11]. Geogebra is used in this study to help students solve the problems of a linear program in three variables. Based on the experience of the researcher during the lecturing program linear there are still many students who have difficulty determining the local extreme points of the set in the resolution of problems of a linear program in three variables by using graphical method.

\section{Methods}

This research is quantitative research with quasi-experiment that aims to determine whether there are differences in the achievement and improvement of mathematical problem posing of students between the use of GeoGebra with that do not use the GeoGebra better overall, and based on initial ability. The subjects of this study are among the 70 students of the third semester of the two existing classes. Test device used: ability test of early mathematical ability test, mathematical problem posing,observation sheet,

\section{Result and Discusion}

\subsection{Result}

To know the results of the achievement and improvement of ability of mathematical problem posing before and after administration of the treatment carried out the test. From the results of the ability test initial and final test or pencapian mathematical problem posing is then calculated score increase in mathematical problem posing by using gain normalized.

The following example of the workmanship problems of a linear program in three variables which is done manually and GeoGebra. Be aware of the system of linear equations as follows:

$$
\left\{\begin{array}{c}
x+y+z \leq 500 \\
y \leq 300 \\
z \leq 300
\end{array}\right.
$$




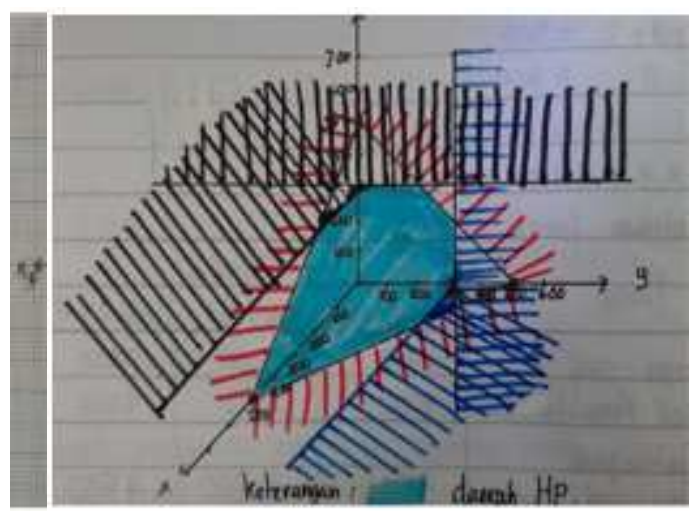

Figure 1. Completion of the Graphical Method Manually

Figure $\quad 1$
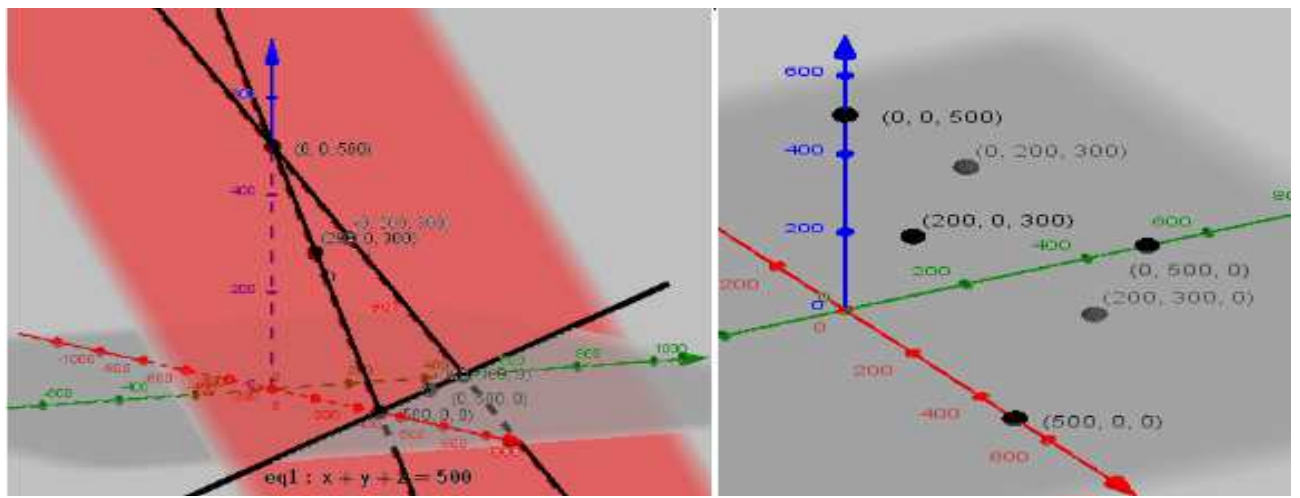

Figure 2. Completion of Graph Methods with Geogebra

shows the results of the work of students who solve the problems of linear programming threevariable manually. Most of the students could not solve the matter because of the difficulty to determine the extreme points of the regional set of finishing of smoke. Figure 2 shows the results of the work of students who solve the problems of the program three linear variable in GeoGebra. With the help of GeoGebra student easier to determine the extreme points of the area of the set of settlement.

Overview of achievement of ability in mathematical problem posing are presented in Table 1. 
Table 1. Test the Achievement of the Ability of Problem Posing Overall

\begin{tabular}{|c|c|c|c|c|c|c|c|c|c|c|}
\hline & & \multicolumn{2}{|c|}{$\begin{array}{l}\text { Levene's } \\
\text { Test for } \\
\text { Equality of } \\
\text { Variances }\end{array}$} & \multicolumn{5}{|c|}{ t-test for Equality of Means } & \multicolumn{2}{|c|}{$\begin{array}{l}95 \% \text { Confidence } \\
\text { Interval of the } \\
\text { Difference }\end{array}$} \\
\hline & & $\mathrm{F}$ & Sig. & $\mathrm{t}$ & df & $\begin{array}{l}\text { Sig.(2- } \\
\text { tailed) }\end{array}$ & $\begin{array}{l}\text { Mean } \\
\text { Differen } \\
\text { ce }\end{array}$ & $\begin{array}{l}\text { Std. Error } \\
\text { Differenc } \\
\mathrm{e}\end{array}$ & Lower & Upper \\
\hline \multirow{2}{*}{$\begin{array}{l}\text { Overall_- } \\
\text { Achieve- } \\
\text { ment }\end{array}$} & $\begin{array}{l}\text { Equal } \\
\text { variances } \\
\text { assumed }\end{array}$ & $\begin{array}{l}.29 \\
4\end{array}$ & .589 & 10.128 & 68 & .000 & 3.825 & .377 & 3.071 & 4.57864 \\
\hline & $\begin{array}{l}\text { Equal } \\
\text { variances not } \\
\text { assumed }\end{array}$ & & & 10.032 & $\begin{array}{l}60.29 \\
5\end{array}$ & .000 & 3.825 & .381 & 3.062 & 4.58760 \\
\hline
\end{tabular}

From Table 1 , it is known that the probability value (Sig.) $=0.000<0.05$, meaning that there are differences in the average achievement of the ability problem posing overall between using GeoGebra with not using GeoGebra.

Table 2. The Difference In Achievement Of Problem Posing Based On The Ability Of Early

\begin{tabular}{llllll}
\hline & $\begin{array}{c}\text { Sum of } \\
\text { Squares }\end{array}$ & df & Mean Square & F & Sig. \\
\hline Between Groups & 185.667 & 2 & 92.833 & 26.877 & .000 \\
Within Groups & 231.419 & 67 & 3.454 & & \\
Total & 417.086 & 69 & & & \\
\hline
\end{tabular}

From Table 2, it is known that the probability value (Sig.) $=0.000<0.05$, meaning that there are differences in the average achievement of the ability of problem posing based on the initial ability between using GeoGebra with not using GeoGebra.

Overview increase the ability of problem posing are presented in the following table.

Table 3. Differences In The Ability To Problem Posing Overall

\begin{tabular}{|c|c|c|c|c|c|c|c|c|c|c|}
\hline & & \multicolumn{2}{|c|}{$\begin{array}{l}\text { Levene's } \\
\text { Test for } \\
\text { Equality of } \\
\text { Variances }\end{array}$} & \multicolumn{5}{|c|}{ t-test for Equality of Means } & \multicolumn{2}{|c|}{$\begin{array}{l}95 \% \text { Confidence } \\
\text { Interval of the } \\
\text { Difference }\end{array}$} \\
\hline & & $\mathrm{F}$ & Sig. & $\mathrm{t}$ & df & $\begin{array}{l}\text { Sig. }(2 \\
- \\
\text { tailed) }\end{array}$ & $\begin{array}{l}\text { Mean } \\
\text { Difference }\end{array}$ & $\begin{array}{l}\text { Std. Error } \\
\text { Difference }\end{array}$ & Lower & Upper \\
\hline $\begin{array}{l}\text { Overall_ } \\
\text { gain }\end{array}$ & $\begin{array}{l}\text { Equal } \\
\text { variances } \\
\text { assumed } \\
\text { Equal } \\
\text { variances } \\
\text { not } \\
\text { assumed } \\
\end{array}$ & .381 & .539 & 10.350 & 60.976 & .000 & .27608 & .02668 & .22274 & .32943 \\
\hline
\end{tabular}


From Table 3, the probability value is (Sig.) $=0.000<0.05$, meaning that there are differences in the average increase in the ability of problem posing overall between using GeoGebra with not using GeoGebra.

Table 4. Differences In Problem Posing Based On The Ability Of Early

\begin{tabular}{lccccc} 
& \multicolumn{1}{c}{$\begin{array}{c}\text { Sum of } \\
\text { Squares }\end{array}$} & df & Mean Square & F & Sig. \\
\hline $\begin{array}{l}\text { Between } \\
\text { Groups }\end{array}$ & .932 & 2 & .466 & 26.184 & .000 \\
$\begin{array}{l}\text { Within } \\
\text { Groups } \\
\text { Total }\end{array}$ & 1.193 & 67 & .018 & & \\
\hline
\end{tabular}

From Table 4, it is known that the probability value (Sig.) $=0.000<0.05$, meaning that there are differences in the average achievement of problem posing abilities based on initial capabilities between those who use GeoGebra and those who do not use GeoGebra.

\subsection{Discussion}

The results of the overall study and initial ability shows that the achievement and improvement of ability of mathematical problem posing of students who use GeoGebra better than students who did not use GeoGebra. This shows the GeoGebra gives a positive impact on the students to be able to develop the ability of mathematical problem posing. Problem posing is not always the case in complex problem solving, problem posing can happen when filing an issue based on experience. Problem posing as it occurs prior to any troubleshooting, and when the situation is conditioned [13]. In other words, problem posing is the process of activities carried out by students to construct the interpretation of the concrete situation that it faces based on previous experience. Thus, problem posing provides an opportunity to interpret and analyze the reality critically so that: 1) students can distinguish significant data from that is not real, 2) find the relation antardata, 3) specify the information which is suitable to resolve the problem so that in accordance with the results of the study that mathematical problem posing can increase the creativity of students [6]. Lowrie stated that problem posing is considered as a tool of development to think critically because it can help students expand what they know in order to develop fluency in mathematical and involve them in high level thinking [14]. So that it can improve self-esteem [15].

\section{Conclusion}

The application of GeoGebra can help students to develop the ability of mathematical problem posing. Using Geogebra makes it easy for students to continue to try various linear program problems of three variables viewed from different perspectives. Thus GeoGebra is effective for improving mathematical problem posing ability in Linear Program material.

Acknowledgment. Further thanks to the IPI-Garut Rector and FITS-IPI Garut Dean, who has helped and facilitated the authors in conducting research and publications. 


\section{References}

[1] K. Popper, All Life is Problem Solving, First. German: Taylor and Francis, 1999.

[2] D. H. Jonassen, "Research Issues in Problem Solving," pp. 1-15, 2010.

[3] Groves and Susie, "Developing Mathematical Proficiency," J. Sci. Math. Educ. Southeast Asia, vol. 35, no. 2, pp. 119-145, 2012.

[4] J. Kilpatrick, "Problem formulating: Where do good problems come from?," in Cognitive science and mathematics education, 1987.

[5] C. Bonotto, "Artifacts as sources for problem-posing activities," Educ. Stud. Math., vol. 83, no. 1, pp. 37-55, 2013, doi: 10.1007/s10649-012-9441-7.

[6] F. M. Singer, N. Ellerton, and J. Cai, "Problem-posing research in mathematics education: New questions and directions," Educ. Stud. Math., vol. 83, no. 1, pp. 1-7, 2013, doi: 10.1007/s10649-013-9478-2.

[7] N. F. Ellerton and P. C. Clarkson, "Language factors in mathematics teaching and learning," in International Handbook of Mathematics Education, 1996.

[8] A. Shriki, "A Model for Assessing the Development of Students' Creativity in the Context of Problem Posing," Creat. Educ., vol. 04, no. 07, pp. 430-439, 2013, doi: 10.4236/ce.2013.47062.

[9] N. F. Ellerton, "Engaging pre-service middle-school teacher-education students in mathematical problem posing: Development of an active learning framework," Educ. Stud. Math., vol. 83, no. 1, pp. 87-101, 2013, doi: 10.1007/s10649-012-9449-z.

[10] F. M. Singer and C. Voica, "A problem-solving conceptual framework and its implications in designing problem-posing tasks," Educ. Stud. Math., vol. 83, no. 1, pp. 926, 2013, doi: 10.1007/s10649-012-9422-X.

[11] N. Arbain and N. A. Shukor, "The Effects of GeoGebra on Students Achievement," Procedia - Soc. Behav. Sci., vol. 172, no. 2007, pp. 208-214, 2015, doi: 10.1016/j.sbspro.2015.01.356.

[12] Z. A. Reis, "Computer supported mathematics with Geogebra," Procedia - Soc. Behav. Sci., vol. 9, pp. 1449-1455, 2010, doi: 10.1016/j.sbspro.2010.12.348.

[13] E. A. Silver, "On Mathematical Problem Posing," Educ. Stud. Math., vol. 1, no. July 1993, pp. 19-28, 1994.

[14] R. Rosli, D. Goldsby, and M. M. Capraro, “Assessing students' mathematical problemsolving and problem-posing skills," Asian Soc. Sci., vol. 9, no. 16 SPL, pp. 54-60, 2013, doi: $10.5539 /$ ass.v9n16p54.

[15] X. Y. Van Harpen and N. C. Presmeg, “An investigation of relationships between students' mathematical problem-posing abilities and their mathematical content knowledge," Educ. Stud. Math., vol. 83, no. 1, pp. 117-132, 2013, doi: 10.1007/s10649012-9456-0. 